\title{
RETHINKING THE ROLE OF KIAI LEADERSHIP IN MODERNIZING PESANTREN IN CIANJUR, WEST JAVA
}

\author{
Abdul Wahid Hasyim \\ Universitas Islam Negeri Syarif Hidayatullah Jakarta \\ Jl. Ir. H. Juanda No.95, Tangerang Selatan, Banten, 15412 \\ e-mail: abd.wahid@uinjkt.ac.id
}

\begin{abstract}
This article seeks the role of the Kiai in the modernization of pesantren in Cianjur, West Java. Taking the cases of Pesantren al-Musyarrofah, Pesantren Darul Falah, Pesantren as-Syuja'i, and Pesantren Darussuada al-Amin, this research uses qualitative methods. The study found that although these Pesantrens played a significant role in da'wah, education, and the development of socio-religious institutions in Cianjur, their existence of experienced ups and downs due to the management system practiced by the pesantren leadership. In addition, it was also implied that modern management combined with the Kiai charisma has become a success factor in the modernization of the pesantren.
\end{abstract}

Abstrak: Artikel ini berupaya mengkaji peran kiai dalam modernisasi pesantren di Cianjur, Jawa Barat. Dengan memokuskan pada kasus Pesantren al-Musyarrofah, Pesantren Darul Falah, Pesantren as-Syuja'i dan Pesantren Darussuada al-Amin, penelitian ini menggunakan metode kualitatif. Berdasarkan penelitian yang dilakukan ditemukan fakta bahwa meskipun berperan besar dalam bidang dakwah, pendidikan, dan pengembangan pranata sosial keagamaan di Cianjur, keberadaan keempat pesantren mengalami pasang surut yang disebabkan oleh sistem manajemen yang dipraktikan oleh pimpinan pesantren. Penelitian ini juga mengimplikasikan bahwa manajemen modern yang dipadukan dengan kharisma Kiai menjadi faktor keberhasilan modernisasi pesantren.

Keywords: Islamic education, pesantren, kiai, management, leadership 


\section{Introduction}

In two of his works on Islamic education, Hefner emphasized that Islamic education is entirely a social phenomenon in which knowledge, politics, and social networks interact in the context of tricky achievements. Islamic education has emerged as an essential prism, but so far, it has not become a starting point for understanding Islam's face in Southeast Asia, especially Indonesia. ${ }^{1}$

The modernization of Islamic education is Hefner's starting point in both books. With a comparative model, Hafner compared the Islamic education system in several countries. One of the findings is about ulama's position as leaders of religious schools and their relationship with the state. In the context of printing, modern Muslims-in Hefner's term, making modern Muslims-ulama are an essential element whose position often faces various challenges.

Modern developments facing various countries, including Indonesia, have influenced the form, transmission, and meaning of Islamic science. The historical context and social environment in which Islamic education previously developed can be a starting point for understanding the dynamics of Islamic education, including its implications for changing the state's cultural and political landscape. The transmission of Islamic knowledge, according to Hefner, always depends on the support of social and political authorities. According to him, Islamic knowledge transmission was always dependent on social and political authorities' support. Embedded as it was in specific social arrangements, religious education changed as the society in which it was located did. However, the institutions involved in transmitting Islamic knowledge did not shift with every new wind that blew across the landscape. The traditions with which Muslim scholars ('ulamâ') were concerned included many viewed as divinely revealed. Scholars and teachers had to balance their efforts to demonstrate God's message's urgent relevance, then, with a normatively "conservational" preservation of its eternal truths. ${ }^{2}$

Hefner's explanation provides an overview of the ulama's urgency in the process of modernizing Islamic education. The state-sponsored education system has become an essential tool in the experience of Muslim political modernity. This often creates tension but soon returns to harmony. In the most influential Muslim country of the early modern era, the Ottoman Empire, the "modernization" of religious education began several centuries before Western powers achieved military supremacy. The modernity of education here is not the postcolonial effect of the Western rule. After Turkish armies moved to western Anatolia in the fourteenth and fifteenth centuries (culminating in the capture of Constantinople

${ }^{1}$ Robert W. Hefner, Making Modern Muslims, The Politics of Islamic Education in Southeast Asia (Honolulu: Univerity of Hawaii Press, 2009); Robert W. Hefner \& Zaman, Muhammad Qasim (ed.), Schooling Islam, The Culture and Politics of Modern Muslim Education (New Jersey: Princeton University Press, 2006).

${ }^{2}$ Hefner, Schooling Islam, p.4. 
in 1453), the Sultan established madrasas (Turkish, medrese) throughout the conquered territories. From the very beginning, madrassas and 'ulama were used to train the Ottoman state. In the late 15th century, Ottoman authorities organized and centralized madrassas in their core territories. They classify and rank religious schools in a strict hierarchy. Ottoman officials also established educational criteria under which scholars were demoted from lower ranks to higher religious hierarchy ranks. ${ }^{3}$

Suleiman the Magnificent (r. 1520-1666) added another tier to the madrasa hierarchy, named the Istanbul mufti the first of all 'ulamâ' and set the procedure by which elected clerics were recruited for government service. Islamic education's rationalization peaked in the eighteenth century, with eleven levels of madrasas differentiated by prestige, teaching staff, and salary. By this time, however, Ottoman rule was starting to decline, and government officials were beginning to appreciate that Western Europe had developed a military and technological advantage over its old rivals. The sultan's advisor concluded that the "secret wisdom" behind Europe's advantages was education. ${ }^{4}$

The history of Islamic education in Turkey above emphasizes tension and harmonization between ulama and the state, which is typical. History also records that in the past, rulers and viziers had their ideas about the form and purpose of religious education, which also influenced the development of Islamic education. In modern times something similar happened. Especially in the last two centuries, the phenomenon of the emergence of a healthy interventionist state, with different educational ambitions from the ulama, took place in many countries, including in the archipelago. Western nations' progress with existing market forces, media, and knowledge technology also determine Muslims' scientific transmission. Especially in the nineteenth and twentieth centuries, Muslim scholars, including clerics, attempted to adapt to globalization. This, in turn, helped change the face of Islamic education, which became essential and strategic in building the nation-state. Islamic schools, including Pesantren, are institutions for teaching and training Muslim youth in the basic sciences of religion and producing future actors rich in reform ideas. ${ }^{5}$

Indonesia, like other Islamic countries, is involved in a series of Islamic education modernization programs. In this process, scholars and other religious elites were involved and had a significant influence. Even in the local context, these religious elites entered into a conflict circle due to their different responses to developments in Europe. Then came the rivalry between the two central Muslim elites: the "old" traditionalist group (the old) and the "new" modernist group (the youth). Nevertheless, despite their sectarian competition, both groups agree on the importance of educational reform. In the late 1920s, traditionalist and modernist Islamic schools incorporated mathematics, science, history, and European

\footnotetext{
${ }^{3}$ Ibid.

${ }^{4}$ Ibid.

${ }^{5}$ Ibid.
} 
languages into the curriculum. These early precedents paved the way for bolder developments in Islamic education during the last decades of the twentieth century when Indonesians embarked on some of the most ambitious religious education reforms in the Muslim world. ${ }^{6}$

Hefner's findings above are interesting to examine in more depth, especially to see the contemporary portrait of Islamic education in traditional educational institutions, pesantren. The argument that modernizing Islamic education is supported by the role of ulama as leaders of religious schools (including, in this case, pesantren) is still valid today. The leadership of the Kiai is still very decisive in the effort to produce modern Muslims. Until now, the pesantren's success in modernizing education has been determined by the Kiai leadership in changing the management of the pesantren.

The issue of Kiai leadership in changing pesantren management has been reviewed by several academics, Imron Arifin in his research entitled Kiai Leadership: The Case of the Tebu Ireng Pesantren. According to him, Kiai has an essential role in the modernization of pesantren. The figure of Kiai as a leader who is trusted, obeyed, and imitated by the community he leads is the primary capital of modernizing the Tebuireng Pesantren. Kiai's leadership is adhered to because they have mastery of information, professional expertise, and moral strength. The personal charm displayed makes a Kiai loved and used as a role model as an exemplary figure and a source of inspiration for the community he leads. The more consistently and consistently a Kiai meets the criteria and prerequisites for exemplary leadership, the stronger he will be made a leader, not only by the pesantren community he leads but also by all Muslims and the broader community on a regional, national and international scale.

In this context, Arifin took the case of $\mathrm{KH}$ charismatic leadership. M. Hasyim Asy'ari and $\mathrm{KH}$. Abdul Wahid Hasyim succeeded in building a pesantren to achieve the ideal standards of an Islamic educational institution. Although initially, it received excellent resistance from the community, gradually, with the charisma possessed by Kiai Hasyim, there was growing recognition from the community, including from the Dutch government, which only officially recognized the Tebuireng pesantren on February 6, 1906. an increasing number of students enrolled in Tebuireng, not only from the Jombang region but also from various Java and Madura regions. From only 28 people at the beginning of its establishment to nearly 2000 students in $1920 .^{7}$

In his second research on pesantren-based educational and managerial leadership, Arifin again emphasized that the Kiai leadership had succeeded in delivering the Tebuireng

${ }^{6}$ Azyumardi Azra, Dina Afriyanti and Robert W. Hefner, "Pesantren and Madrasa: Muslim Schools and National Ideals in Indonesia," in Schooling Islam, The Culture and Politics of Modern Muslim Education (New Jersey: Princeton University Press, 2006), p. 182-5.

${ }^{7}$ Imron Arifin, Kepemimpinan Kiyai: Kasus Pondok Pesantren Tebu Ireng (Malang: Kalimashada Press, 1993), p. 30. 
pesantren in the process of modernizing education through quality-based and futuristicoriented paradigm changes that were realized practically, through the field of education, the field of queuing, the field of human resources, infrastructure, finance, and public relations. According to Arifin, the Kiai educational background is crucial for the pesantren's paradigm shift and quality management. ${ }^{8}$

This article seeks to strengthen Hefner's findings regarding the vital role of religious elites in transforming Islamic education and the leading factor of Kiai in the modernization of pesantren, as revealed by Arifin. In the process of looking for these similarities (compare), 4 Pesantren in Cianjur, West Java, will be examined, namely the Al-Musyarrofah Islamic Boarding School, the Darul Falah Islamic Boarding School, the As-Syuja'i Islamic Boarding School, and the Darussuada al-Amin Islamic Boarding School. The article seeks to portray aspects of continuity and change in each pesantren. How ready are the pesantren leaders to accept the demands of global change, or vice versa? Why do they seem less prepared to welcome the modernization of education that should have become a necessity? What is the portrait of the management and leadership of the Kiai in the modernization of the pesantren today? Why are some pesantren successful but others fail to modernize education?

\section{Methodology}

This research uses the descriptive-analytical method. A literature search is done by collecting books, articles, and research results on pesantren in Indonesia. Using qualitative methods with historical and phenomenological approaches, this research seeks to reveal pesantren's management in Cianjur, West Java, with a case study of the Musyarrofah pesantren, Darul Falah pesantren, as-Syuja'i pesantren, and Darussuada al-Amin pesantren. Data collection is carried out other than through studies literature also direct observation. To enrich the information and sharpen the analysis, this research is also equipped with library research from various sources, such as books, magazines, newspapers, and related sources, relating to the subject matter research and pesantren's role in Cianjur, West Java.

This study's urgency is to understand the importance of management in pesantren in this modern and global era. Pesantren still relies on the management model paternalistic. Relationships are often used by managers pesantren without prioritizing professionalism. This kind of pattern indeed becomes a barrier to developing and improving the quality of education in pesantren. Otherwise, with modern management, pesantren have developed and continue to exist in the flow of modernization and globalization.

${ }^{8}$ Imron Arifin dan Muhammad Slamet, Kepemimpinan Kyai dalam Perubahan Manajemen Pondok Pesantren: Kasus Ponpes Tebuireng Jombang (Yogyakarta: CV Aditya Media, 2010). 


\section{Results and Discussion}

\section{Al-Musyarrofah Pesantren}

Al-Musyarrofah pesantren was founded in 1833 by Shaykh Tb. Abdullah Umar Syarifuddin. ${ }^{9}$ They are located in Ciwalen, Warung Kondang sub-district, on one hectare of land waqf from Adipati Rd. Aria Wiratanu Datar IV (Rd. Siti Bodedar) - this pesantren practices a traditional system. This pesantren can be called as salafiyah (salaf) Pesantren. Understanding salaf here does not understand Islam's flow, but an education system in pesantren like a curriculum in schools. In this case, the salaf shows an education system that refers to the classic books as a guide. The primary method of teaching the system used is the sorogan system. ${ }^{10}$ Through this sorogan system, every student gets an opportunity to learn directly from the Kiai or kiai's assistants. This system is usually given in recitation to students who have mastered the reading of the Qur'an. This sorogan system is used in formal classes. The term sorogan comes from the word sorog (Javanese), which means handing out a book to the Kiai. ${ }^{11}$

Besides, bandongan ${ }^{12}$ Moreover, the wetonan ${ }^{13}$ Systems are also used, which are often called collective schemes. In the bandongan order, a group of students listens to a teacher who reads, translates, and explains Arabic books. This class group from the bandongan system is called halaqah, which means a group of students studying under a teacher's guidance. While the wetonan system is used for other study areas, and the time is outside of study hours. This pattern, in the experts' view of more results, so many parties tend to practice it, because it is in line with the third realm in teaching and learning activities, namely

9 Shaykh Tb Abdullah Umar Syarifuddin is a cleric whose line from Mother's path to Abdul Muhyi Pamijahan to Sunan Giri Gresik, while from the father's line, his lineage to Shaykh Manshuruddin Cikaduen to Sunan Gunung Jati Cirebon Founder of Tebuireng Pesantren, Jombang, East Java. Abdul Wahid Hasyim, Pesantren Langitan Pusat Pencerahan Intelektual Ummat (Bekasi: Pascasarjana Unisma, 2008), p. 50; Zamakhsyari Dhofier, Tradisi Pesantren Studi Tentang Pandangan Hidup Kyai (Jakarta: LP3ES, 1982), p. 25.

${ }^{10} \mathrm{~A}$ recitation system in which students come to the teacher one by one by bringing the book they will study. The Kiai reads the Arabic language sentence by sentence, then translates it and explains its purpose. The student listens and notes the book to confirm that the Kiai has given knowledge. Sorogan comes from Javanese sorog, which means to offer because every student offers his book in the presence of the Kiai or his assistant. Muhammad Dawam Rahardjo, Pesantren Dan Pembaharuan (Jakarta: LP3ES, 1974), p. 88.

${ }^{11}$ Sukamto, Kepemimpinan Kiai Dalam Pesantren (Jakarta: LP3ES, 1999), p. 144.

12 The teaching system provided to a group of students consists of 5-500 people by listening to a teacher read, translate, explain, and often review Islamic books in Arabic. Each student pays attention to his writing and makes notes about difficult words or thoughts. Dhofier, Tradisi Pesantren Studi Tentang Pandangan Hidup Kyai, p. 28.

${ }^{13}$ Lecture teaching system teaches students to take lessons by sitting around the Kiai who explain the lecture. Students listen to each book and make notes on it. Weston is derived from the Javanese language "Wektu," which means time, because the teaching is given at certain times, before or after performing the obligatory prayers. Rahardjo, Pesantren Dan Pembaharuan, p. 88. 
psychomotor or skills. Wetonan in Sumatra is known as balaghan. The term weton comes from the word wektu (Javanese) because the recitation is done at a particular time before and after performing the prayer. ${ }^{14}$

The books taught in fiqh include Safinat al-Najâh, Fath al-Qarîb, Minhâj al-Qawîm, Fath al-Wahhab, al-Mahalli, Fat $\underline{h}$ al-Mu'în and Uqdat al-Farid. In the area of usul fiqh, among others, Farâ'id al-Bahiyah. In the field of monotheism, include 'Aqîdatul. In the field of nahwu, among others, al-Sharaf Tasrifiyat. In the area of balaghah, among others, Jauharat al-Maknûn, Sullam al-Munauroqi. In the field of morals and Sufism include Talim al-Muta'allim, Ihyâ' 'Ulûmuddîn. In the field of interpretation of the Qur'an, among others, Tafsîr Jalâlain. In the field of hadith, among others, Shahîh $\underline{h}$ Bukhârî. In the area of muthala'ah, among others, al-Baiquniyah.

After Shaykh Tb. Abdullah Umar Syarifuddin died in 1854, successive pesantren led by Shaykh Arifuddin (until 1894), KH. Raden Abdul Mu'thi (until 1935), KHR. Abdul Razi Arif and KH. Afandi Zuhdi (until 1975), KH. Wildan Afandi (until 2014), and KH. Acep Abdul Wahid (to date). ${ }^{15}$ In its history, local people recognize pesantren, one of the oldest Islamic education institutions in Cianjur, West Java, as Ciwalen pesantren. This pesantren around 1968 became a stronghold in the fight against the Partai Komunis Indonesia (PKI) rebellion and the mob that disturbed people's security. KH. Afandi Zuhdi, who was then the pesantren's leader, took part as the Barisan Serbaguna (Banser) fighting the PKI. Clash can not be avoided, causing pesantren buildings also burned. As a result, some pesantren facilities were heavily damaged and could not be used to teach and learn. It took several years to restore the function of the pesantren as before. ${ }^{16}$

In 1975, KH. Wildan Afandi began to lead the pesantren. He continued the leadership of KH. Afandi Zuhdi and KH. Abdul Razi Arif, who died at almost the same time, was only four days apart. During this time, there was a change in management, marked by the founding of the foundation and a difference in the name of the Ciwalen pesantren to alMusyarrofah Pesantren. Until 2002, al-Musyarrofah tended to only move in the field of da'wah and human society, until that year a new foundation deed was done by placing Ihas Rafiqah as the Head of Madrasah Diniyah (since 2002), Elis Riana Wildan as the Principal of Taman al-Qur'an Education School (since 2004) and Adi Karyadi as Head of Madrasah Ibtidaiyah, in the same year. Since then, the structuring of development programs began, until in 2008 al-Musyarrofah, modern pesantren was established by establishing al-Musyarrofah Integrated Islamic Middle School (SMP IT), continued in 2011 by creating the Integrated Islamic Vocational Middle School (SMK IT).

${ }^{14}$ Sukamto, Kepemimpinan Kiai Dalam Pesantren, p. 144-145.

${ }^{15}$ Ilham Nugraha, Sejarah Berdirinya Pondok Pesantren Al-Musyarrofah (Cianjur: Pondok Pesantren Modern al-Musyarrofah, 2016), p. 14-15.

${ }^{16}$ Acep Abdul Wahid, Caregiver of al-Musyarrofah Pesantren, interview in Warung Kondang, Cianjur, West Java, September 18, 2018. 
There are 18 students in the first class consisting of 12 men and six women. That number has increased so that in 2018 to 650 people, from 300 people who live in dormitories who are junior and vocational high school students, and 350 non-permanent students are Madrasah Diniyah, Madrasah Ibtidaiyah, and al-Qur'an Education. Teachers and staff as many as 50 people under the pesantren leadership, including KH Acep Abdul Wahid, Ihas Rafiqah, and Elis Riana. ${ }^{17}$

\section{Darul Falah Pesantren}

Darul Falah pesantren is located in Jambudipa village, Warung Kondang District. Based on the explanation of a pesantren manager, 1894 was the pesantren establishment's estimated year. This refers to information from Abah Imaging (died in 1984 at the age of more than 100 years). This pesantren originated from the arrival of a wandering man from Sambong Village, Tasikmalaya, and settled in Jambudipa. At that time, there was no musholla in Jambudipa, let alone a mosque. Its citizens embraced Islam for generations and did not study Islam properly. That reality was encouraging men from Sambong, KH. Muhammad Chalil, known by the people by Baing Sambong, to establish mosques and teach Islamic religion in the region. ${ }^{18}$

Through the mosque and pesantren he founded, $\mathrm{KH}$. Muhammad Chalil tried to change Jambudipa Village people's lives by practicing Islam through recitation and education. As a hafiz of the Qur'an, KH. Mohamad Chaliil ${ }^{19}$ Started his study at Darul Falah pesantren by teaching him how to write and read the Qur'an. Very many students. They come from various regions. Apart from Jambudipa Village, they came from the surrounding villages, and some even came from very far away areas. Both permanent and non-permanent students motivate the Kiai to build a simple hostel to accommodate several students. However, in subsequent developments, more and more students who want to stay overnight and boarding becomes more crowded, so KH. Muhammad Chalil built another dormitory that could accommodate 100 students. The hostel was later named Pondok Santosa.

${ }^{17}$ Elis Riana, Caregiver of al-Musyarrofah Pesantren, interview in Warung Kondang, Cianjur, West Java, September 19, 2018.

${ }^{18}$ Ade Ismail, Caregiver of Darul Falah Pesantren, interview in Jambudipa, Cianjur, West Java, August 13, 2018. So, the founding period of Darul Falah Pesantren was almost at the same time as the establishment of the Gentur Pesantren, which was established by KH. Qurtubi or Mama Kidul who was born in 1870 in Gentur Village, Jambudipa Village, Warung Kondang District, and was raised with his younger brother $\mathrm{KH}$. Ahmad Syatibi or Mama Kaler and was born in 18701872 in Nagrak Village, Cianjur District. After being given waqf land, Mama Kaler opened her pesantren in Gentur. This pesantren then in 1918 developed and became famous because many gave birth to the Kiai of the founder of the pesantren, which were spread throughout the archipelago, which was estimated to number as many as 3000 Kiai. KHR. Abdul Halim, Rudi Asyarie, and Ending Bahrudin, Kyai Dari Tatar Murid (Cianjur: Yaspumah, 2014), 110-111.

${ }^{19}$ Ade Ismail, Caregiver of Darul Falah Pesantren, interview in Jambudipa, Cianjur, West Java, August 13, 2018. 
In 1917, KH. Muhammad Chalil died. ${ }^{20}$ Furthermore, his son-in-law, KH. Fachruddin, replaced his position as caretaker and leader of the Darul Falah Pesantren. Initially, KH. Fachruddin, who came from Songgong Village, Warung Kondang, studied at the Gentur pesantren and studied with KH. Ahmad Syatibi, then studied at Darul Falah pesantren in Jambudipa by analyzing KH. Muhammad Chalil. Because of his skill, KH. Fachruddin was married to his daughter. Even after KH. Muhammad Chalil died, he was given the task and mandate to lead the Darul Falah pesantren. During his leadership, Darul Falah pesantren grew, and his students improved more and more.

Darul Falah pesantren Jambudipa can be classified into traditional pesantren because it only organizes sermons in the sorogan, bandongan, or balagan, and wetonan. In addition to studying the Qur'an, students also study the books of the salaf (books of classical ulama), such as Nahwu Science, Neurology, Fiqh, Interpretation, Tasawuf, and other Islamic sciences. In 1935, KH. Fachruddin founded the majelis ta lim as a routine recitation for the surrounding community residents and bats students who want to study at the pesantren. The study is currently ongoing and is carried out every Monday for men and Tuesday for women.

In 1962, KH. Fachruddin founded the Madrasah Diniyah. The aim is to meet the community's needs in education and strike a balance between general knowledge obtained at the elementary school level and religious education at the Madrasah Ibtidaiyah. More than that, KH. Fachruddin also established the Ibtidaiyah Madrasah in the vast pesantren complex while inaugurating Darul Falah as the pesantren name has increasingly grown.

In 1965, KH. Fachruddin died, and his position as a caregiver was replaced by his eldest son, KH. Aang Muhyiddin, better known as Aang Endang Jambudipa and assisted by other sons and his son-in-law, including KH. Daud Jalaluddin, KH. Tb Ahmad Zaha, KH. Masykur, KH. Ghufran, KH Falahuddin, KH. Badrul Mukarram, KH. Deden Saefuddin, and $\mathrm{KH}$. Sarhindi, in the form of collegial collective leadership and not focused on the central figure. During his administration, KH. Aang Muhyiddin, Darul Falah pesantren, is increasingly popular and is known by the wider community to reach East Java, including Madura. In addition to continuing the book's tradition, salaf (the text of classical scholars) carried out by KH. Fachruddin also developed a book study specifically for the Kiai, who led the pesantren majelis talim. Besides, KH. Aang Muhyiddin is also known as a charismatic Kiai, who is an expert in the field of wisdom (mysticism/tarekat science) so that many students come to study it, even officials from the center, especially during the new order during the Soeharto administration, many came in touch to visit Darul Falah pesantren. ${ }^{21}$

In 1978, a fire broke out, which burned down the dormitory building, which in addition

${ }^{20}$ Muhammad Chalil studied the Qur'an until he memorized it for nine years in Makkah al-Mukarramah. Ibid, 18.

${ }^{21}$ Ade Ismail, Caregiver of Darul Falah Pesantren, interview in Jambudipa, Cianjur, West Java, August 13, 2018. 
to being a place for students to study, also became a place for the grave of $\mathrm{KH}$. Aang Muhyiddin and family. In 1983, Darul Falah pesantren received assistance from the Minister of religion in the form of a building, ten units of sewing machines, 1 unit of overlock machine, 1 unit of the knitting machine. The assistance is given to equip students with sewing skills as provisions for independent living.

After KH. Aang Muhyiddin died, Darul Falah pesantren was led by collegial, but the elder and healed were KH. Buldan. According to the rules, institutionally, pesantren began to form a Foundation, with KH. Buldan teaches the yellow book, just as it has been directed to the Kiai before. Some manage Madrasah Diniyah, some manage facilities and infrastructure, and some communicate with outsiders, such as $\mathrm{KH}$. Ade Ismail. Some of them preached outside the pesantren and became members and administrators of Nahdlatul Ulama mass organizations such as KH. Chairul Anam and others. ${ }^{22}$

\section{As-Syuja'i Pesantren}

Pesantren as-Syuja'i pesantren started with a man named H. Husen, who worked on his vacant land in Ciharashas Village, Sirnagalih Village, Cilaku District, Cianjur Regency, West Java. At that time, Ciharashas was a quiet village, far from the crowds. Its population is still underdeveloped and left behind in education. Many of them do not know both public and religious. His character is still low, and his outlook and thinking are still weak. This condition caused H. Husen to be disturbed and called to build a house, a mosque, and a female pesantren. ${ }^{23}$ After the cottage complex was built around 1938, all assets in the form of land, all the buildings, and rice fields were handed over to Mama H. Muhammad Syuja'i, ${ }^{24}$ His son-in-law, who married his daughter Hj. Siti Khadijah bint H. Husen bin H. Ibrahim bin Yunus. From his mother's line, named Hj. Masirah Binti H Ghazali bin KH. Shelah, Kiai Buni Kasih Kidul, Warung Kondang District, Cianjur Regency. His wife, Hj. Siti Khadijah, graduated from Vervlog School and studies at the Gentur pesantren, Warung Kondang, Cianjur. During the marriage, KH. Muhammad Syuja'i was not blessed with offspring, but his family remained harmonious. Even Muhammad Syuja'i mother referred to his wife as the "Minister of the Interior" because he could take care of the household well.

Education KH. Muhammad Syuja'i started as a child by learning to read and write the Qur'an to his father while studying in the Village School and the Dutch School Vrvolg School. After finishing, he went to Garut and studied at the Garut Sumursari pesantren

${ }^{22}$ Chairul Anam, Caregiver of Darul Falah Pesantren, interview in Jambudipa, Cianjur, West Java, August 14, 2018.

${ }^{23}$ Halim, Asyarie, and Bahrudin, Kyai Dari Tatar Murid, p. 88.

${ }^{24}$ Born on Wednesday, 15 June 1920, in Sukaraja, Sukabumi, West Java. KH. Abdul Aziz Hidayatullah, Caregiver of as-Syuja'i Pesantren, interview in Cilaku, Cianjur, West Java, September 13, 2018. Ibid, p. 86-87. 
in West Java. A year at this pesantren, he moved to the Gentur pesantren, Warung Kondang Subdistrict Cianjur, studying with KH. Ahmad Qurtubi/Mama Kidul and KH. Ahmad Syatibi/Mama Kaler from 1929-1939. Then, he studied with KH. Raden Husen bin KH. Arsyad/Mama Ciajag, Cianjur, studied with KH. Junaedi/Mama Penghulu in Tangerang Banten, studied with Mama KH. Mas Mansur, Astronomy/Astrology Expert (Falak expert) at Jembatan Lima, West Jakarta, studied with Mama al-Habib Ali al-Alatas, Bungur, Cikini, Jakarta, studied with Mama al-Habib Ali al-Habsyi, Kwitang, Central of Jakarta, studied with Mama al-Habib Muhammad al-Haddad, Central Java, and studied with Mama alShaykh bin Salim al-Attas, Sukabumi, West Java. ${ }^{25}$

During the KH. Muhammad Syuja', this pesantren is experiencing very rapid development. Students come from various regions, such as Cianjur, Bandung, Sukabumi, Bogor, Garut, Banten, Jakarta, and others. Because of his progress, the pesantren was named after the Kiai, who developed it, namely as-Syuja'i pesantren. His name is increasingly fragrant and known because $90 \%$ of students can establish, build, and manage pesantren after returning to their hometowns. Students and alumni of pesantren commonly practice this tradition in other areas.

Students generally learn in the sorogan, wetonan, and bandongan or balagan. So that the as-Syuja'i pesantren can be classified into traditional pesantren. While the knowledge learned includes the science of tools consisting of Nahwu, Sharaf, Mantiq, Bayan, and Ma'ani Sciences; The Science of Hadith uses the book Riyâdh al-Shâlihîn; Interpretation uses the Tafsîr Jalâlain; Fiqh uses the text of Fath al-Wahhâb, but its specialty is the science of the tool so that more and more extensive students come to the as-Syuja'i pesantren to study it, covering almost the entire archipelago, such as North Sumatra, South Tapanuli, Labuhan Batu, Palembang, North Lampung, Kota Bumi, Brebes, Central Java, and East Java and others. ${ }^{26}$

In addition to caring for pesantren, KH. Muhammad Syuja'i also preached from mosque to mosque and from majelis ta lim. ${ }^{27}$ To other ta lim assemblies. He also lectured on every celebration of Islamic holidays, such as in the month of Rajab, the month of Maulid, the month of Muharram, at weddings and circumcision ceremonies with themes

${ }^{25}$ Abdul Aziz Hidayatullah, Caregiver of as-Syuja'i Pesantren, interview in Cilaku, Cianjur, West Java, September 13, 2018. Ibid, p. 86-87.

${ }^{26}$ Abdul Aziz Hidayatullah, Caregiver of as-Syuja'i Pesantren, interview in Cilaku, Cianjur, West Java, September 13, 2018. KHR Abdul Halim, Rudi Asyarie and Ending Bahrudin, Ulama Jumhur Dari Cianjur (Cianjur: Yaspumah, 2016), p. 88.

${ }^{27}$ The term majelis ta'lim comes from Arabic, which means a place of teaching or a place of recitation or a place (container) in which there is a process of teaching and learning about Islam and others for the congregation and its members to achieve predetermined goals. So, majelis ta'lim is a non-formal educational institution that organizes Islamic recitation, has a relatively large number of congregations, a heterogeneous age, a religiously-based curriculum, and flexible timing the needs of the congregation. 
that adapted to the situation at the time. More than that, he was also listed as an activist of the Nahdlatul Ulama (NU) mass organization. While still a student at the Gentur pesantren, he had already pocketed an NU Member Card, making it feasible that almost all of Mama Syuja'i's students were affiliated with NU. He never broke up with NU. Therefore, it is not surprising, after leading the as-Syuja'i pesantren, he received much support from the community to become an administrator of NU. The help came from al-Habib Muhammad al-Haddad, Tegal, Central Java, al-Habib Sheikh bin Salim al-Attas, Sukabumi, West Java, al-Habib Uthman al-Idrus, Bandung. Because of that support, Mama Syuja'i became a branch of the NU branch and was appointed Deputy Rais Syuriah PWNU West Java until her drift in Cianjur in $1983 .{ }^{28}$

In 1961, KH. Syuja'i married his grandson Hj. Ai Afifah Binti H. Buchari, which is Hj. Sunaenah, with KH. Abdul Aziz Hidayatullah, better known as Kiai Dayat, ${ }^{29}$ While Hj. Sunaenah is Hj's niece. Siti Khadijah, wife of Mama KH. Muhammad Syuja'i. Education $\mathrm{KH}$. Hidayatullah started from childhood until graduating from High School. Later, he studied at many pesantren, one of them at as-Syuja'i pesantren, studying with KH. Muhammad Syuja'i at 15 years. Because of his intelligence, skill, and politeness towards others, he was later married to his niece's daughter. Since then, Kiai Dayat became part of the KH. family. Muhammad Syuja'i and later, in 1961, he got the trust and full trust from KH. Muhammad Syuja'i, ${ }^{30}$ To help and manage them as-Syuja pesantren with a total of 800 students. Following the times, KH. Abdul Aziz Hidayatullah began to think about the community's need for a formal school and a balance between general science and religion. Mama KH. Dayat emphasized that this millennial generation must own both of these sciences in this global and modern era. Therefore, after KH. Syuja'i died in 1991, Kiai Dayat founded the "al-Maziyyah Education Foundation" and founded the Middle School and High School. Both institutions turned out to be experiencing very rapid development, the number of students approaching 1000 people. ${ }^{31}$

In addition to caring for pesantren, Kiai Dayat is also active in preaching through recitation at the majelis taklim in his hut, and preaching from mosque to mosque, from one narration to another monologue, from lectures at each commemoration of Islamic holidays, such as at the events of maulidan, Isra Mirraj events, Muharram events, weddings, and others. The study material consists of jurisprudence science, the science of morality, the science of sufism and others. In contrast, the lecture material is discussed with events that occur in everyday life. Besides, Kiai Dayat was also actively coloring district government

${ }^{28}$ Halim, Asyarie and Bahrudin, Kyai Dari Tatar Murid, p. 89-90.

${ }^{29}$ Abdul Aziz Hidayatullah was born on May 17, 1937 in Leles, South Cianjur, from parents who came from Tasikmalaya. The third child of seven siblings, his father's name was $\mathrm{H}$. Hudlari and Ibu Hj Matiah. Halim, Asyarie and Bahrudin, Ulama Jumhur Dari Cianjur, p. 90.

${ }^{30}$ Halim, Asyarie and Bahrudin, Kyai Dari Tatar Murid, p. 90-91.

${ }^{31}$ Halim, Asyarie and Bahrudin, Ulama Jumhur Dari Cianjur, p. 91. 
institutions by preaching through political channels, which is done by becoming a regional Parliament member for three periods. After his term of office ended, in 2006, Kiai Dayat joined a mass organization by becoming a member of the Nahdlatul Ulama, which was to become the Manager of the NU Tanfidziyah Branch of Cianjur Regency, the period 20062011, the same as Mama KH. Muhammad Syuja'i who was also an activist and a member of the NU organization. ${ }^{32}$

\section{Darussuada al-Amin Pesantren}

Darussuada al-Amin Pesantren was founded in 1940 by KH. Ahmad Musthafa Yahya, a student, and son-in-law of KH. Ahmad Syubani bin Husen Mama degree. He is married to the biological sister of Mama Gelar, caregiver for the pesantren of the degree located in the District of Cibber, Cianjur Regency. ${ }^{33}$ After that, he studied at the Gentur pesantren, then considered Mama KH Kiai Ilyas and Mama KH Nahrawi, two very famous scholars in Cibitung, West Bandung Regency. After completing his education at pesantren in Cibitung, $\mathrm{KH}$ Ahmad Musthafa Yahya returned and established Darussuada al-Amin Nyalempet pesantren, Cilaku District, Cianjur Regency. ${ }^{34}$

Darussuada pesantren is a traditional pesantren that teaches Islamic religion in sorogan, bandongan, and tasrifan. The knowledge taught consists of Tauhid, Fiqh, Tasawuf, Jalâlain, Nahwu, Sharaf, Balaghah, and others. But, in particular, in the field of tool science, because of Kiai's favorite book. Ahmad Musthafa Yahya is a Science Tool. ${ }^{35}$ Teaching began in a small mosque, and now it is called al-Ihlas. At first, the mosque was located in the east, then in 1955, it was moved to the west, as it is today. Darussuada pesantren was established on 1 ha of donated land and waqf land. The number of students is minimal, approximately 100 people, do not introduce traditional schools like the Ibtidaiyah level. Students only learn traditionally, and all come to learn, mix, and there are no levels, no separation, and welding. They are mukim students (settled and lived in a dormitory) and generally come from South Cianjur, while those from the surrounding area are bats or go home. ${ }^{36}$

In addition to caring for the pesantren, the Kiai also preach, through routine recitation, every Monday morning for women and Monday afternoon for men, with approximately 30 people, besides teaching out of the hut on every Islamic holiday, such as in the month of

${ }^{32}$ Halim, Asyarie and Bahrudin, Kyai Dari Tatar Murid, p. 91.

${ }^{33}$ Aang Fauzi, Caregiver of Darussuada al-Amin Pesantren, interview in Cilaku, Cianjur, West Java, September 4, 2018. Halim, Asyarie and Bahrudin, Ulama Jumhur Dari Cianjur, p. 21.

${ }^{34}$ Ajeng Masykur, Caregiver of Darussuada al-Amin Pesantren, interview in Cilaku, Cianjur, West Java, September 5, 2018.

${ }^{35}$ Aang Fauzi, Caregiver of Darussuada al-Amin Pesantren, interview in Cilaku, Cianjur, West Java, September 4, 2018.

${ }^{36}$ Aang Fauzi, Caregiver of Darussuada al-Amin Pesantren, interview in Cilaku, Cianjur, West Java, September 4, 2018. 
Maulid and the month of Rajab, Walimatussafar, Walimatulhitan, and others with the material following the conditions and situations related to the history of the birthday with daily life. Kiai preaches from Kelapanunggal, Nariman, and Cidaun to South Cianjur.

After dying in 1990, KH. Ahmad Musthafa Yahya was succeeded by his son KH. Ahmad Shafiyullah as a caregiver. KH. Ahmad Shafiyullah was born in 1948, and in 1973, had assisted his father's activities at the cottage by teaching the Qur'an every morning, evening, and evening prayer. So, he was used to the events of the cabin. Therefore, when he received an assignment and mandate, his activities only continued the tradition abandoned by his father. There was nothing new, except for a year before he died in 2014, he began to open an educational institution classically by establishing the Madrasah Diniyah. Besides, the number of students is stagnant (stagnation/stopping at a place and not adding) and has not increased. However, when the pesantren held the Pesantren Kilat (SANLAT) for a month, the salaries rose sharply, reaching 500 people. They came from students around Darussuada pesantren, and some even came from pesantren in Sukabumi and Banten. According to KH Ahmad Safiyullah, many students in his prayer read, "O God, I want many students, even if it is only one month, it is okay." Besides, during the KH. Ahmad Safiyullah Sanlat occurs five times a year, including 28 Muharram - 28 Safar and is called SANLAT AKBAR, because 20 books are studied, then on 1-20 Ramadan and not called Sanlat Akbar, because only one thick paper is related, related to fiqh, akhlaq tasawuf and tauhid, and from 15-30 Syawal is also not called Sanlat Akbar. ${ }^{37}$

In 2014, KH. Ahmad Shafiyullah died, and his position as caretaker of the hut until now was continued by his son, H. Aang Fauzi. Like his father, he only kept the tradition handed down by his father by holding the pesantren kilat, studying the books at the pesantren both for women and adam, preaching from mosque to mosque lecturing on every commemoration of Islamic holidays. In carrying out his activities at the pesantren, H. Aang Fauzi was assisted by his brother, Ajeng Masykur, his younger cousin managing the Madrasah Diniyah, and his sister maintaining the girls' cottage. So, the three of them taught religion in turns, while the building problem was only H. Aang Fauzi, who took care of it. There are also very few students, approximately 50 female students and 40 male students. They generally study the book's traditional Qur'an and do not study at Madrasah Diniyah, whose level is up to junior high school. He said Darussuada pesantren became crowded and many students if a month's pray was held at this institution. ${ }^{38}$

The Pesantren's brief profile above shows that da'wah is a significant factor driving

\footnotetext{
${ }^{37}$ Ajeng Masykur, Caregiver of Darussuada al-Amin Pesantren, interview in Cilaku, Cianjur, West Java, September 5, 2018.

${ }^{38}$ Aang Fauzi, Caregiver of Darussuada al-Amin Pesantren, interview in Cilaku, Cianjur, West Java, September 4, 2018.
} 
the initiative to establish a pesantren. ${ }^{39}$ If we look at the early history of its establishment, the four pesantren started from someone who settled in a place, then came students who wanted to learn from him, they were students who were bats (not staying and commuting), and some students became settlers (settled and lived in a dorm). Because many students came, a mushalla and mosque, and a hut were built around the kiai's house. In contrast, the land on which the four cabins were built, some were waqf land, gifts from someone, and some were inherited property and remained the status of the Kiai of its founder, which was utilized to benefit the community.

Al-Musyarrofah pesantren in Ciwalen Warung Kondang stands on the waqf land of a noble journalist from Cikundul, Raden Siti Boedidar who holds the title Raden Aria Wiratanu Datar IV, Regent of Cianjur; Darul Falah pesantren Jambudipa, Warung Kondang stands on the land of its founder, KH Mohammad Chalil, also known as Baing Sambong. Ciharashas as-Syuja'i Pesantren, Cilaku stands on the land of its pioneering heir H. Husen, from Bunikasih Kidul, Warung Kondang, Cianjur, while Darussuada al-Amin pesantren in Nyalempit Cilaku stands on the grant land and the inheritance of its founder KH. Ahmad Musthofa Yahya.

The four pesantren were generally set up to change behavior and educate people. Corrupt practices by the local community, such as the habit of cockfighting, gambling, fighting, stealing, going to shamans for guidance, and being heavily influenced by Hindu teachings, are often the main reasons pesantren are established. This is similar to what happened in some pesantren in other areas, such as the Wudang Tuban community before establishing the Langitan Widang Tuban pesantren in 1852, and the Tebuireng community ${ }^{40}$ before the establishment of the Tebuireng pesantren. ${ }^{41}$

That background is what drives the founders of the pesantren, generally as preachers who are migrating, taking the initiative to change the community's bad habits through education. The founder of al-Musyarrofah pesantren is a scholar, who, when drawn from his line of fathers and mothers to Sunan Giri and Sunan Gunung Jati, two of the Nine Wali propagators of Islam on Java. ${ }^{42}$ The Darul Falah pesantren's founder was a traveler from the Kampong of Connect, Tasikmalaya, who came and settled in Jambudipa Village, built a mosque, and taught the Qur'an, and subsequently established a pesantren. The founder of as-Syuja'i pesantren is also a migrant who utilizes vacant land for farming. Still, because he has a significant influence on religion, a pesantren cottage is established on that land. Only the founder of Darussuada al-Amin's pesantren is a native who wants to

${ }^{39}$ Edi Kusnadi, Kadir Sobur, and Arfan Aziz, "A Pesantren: A Study of Al-Mubarok Al-Islam Within the Social Changes of Seberang Kota Jambi," in Addin, Vol. 11, No. 1, 2017, p. 101.

${ }^{40}$ Hasyim, Pesantren Langitan Pusat Pencerahan Intelektual Ummat, p. 84.

${ }^{41}$ Aboebakar, Sejarah Hidup KH. A. Wahid Hasyim (Bandung: Mizan, 2011), p. 87.

${ }^{42}$ Agus Sunyoto, Rekonstruksi Sejarah Yang Dipinggirkan (Jakarta: Transpustaka, 2011), p. $120,154$. 
help change the local community's corrupt traditions. From the four pesantren founders' experience, the motive for da'wah was the main reason for pesantren's establishment in the early days.

\section{Fixing Is/amic Education Institutions:}

\section{Portrait of Pesantren Management}

The four pesantren educational institutions can also be divided into small pesantren, and medium pesantren. Darul Falah pesantren and Darussuada pesantren, the behavior is relatively small because it only has students under five hundred people, and its influence is limited at the district level. Whereas al-Musyarrofah pesantren and as-Syuja'i pesantren are classified as the medium because they have students between five hundred to two thousand students, their influence is quite extensive in several districts.

The four pesantren can be divided into traditional or straightforward, pesantren and semi-traditional or semi-modern pesantren. ${ }^{43}$ Darul Falah pesantren and Darussuada pesantren can be classified into conventional pesantren because they only conduct sermons in the form of sorogan, bandongan, or balagan and wetonan. In contrast, al-Musyarrofah pesantren and as-Syuja'i pesantren can be classified into the pesantren, sorbongan or balagan, and wetonan, while al-Musyarrofah pesantren and as-Syuja'i pesantren semi-modern pesantren, because in addition to organizing the study in sorogan, bandongan or balagan and wetonan, also hosts education in a classical, junior high school level and senior high school level.

Within the management scope, the four pesantren apply a management pattern oriented towards cultivating a spirit of sincerity and volunteerism. This concept animates almost all activities at Pesantren. However, there are many weaknesses related to implementing this management pattern, mainly related to management patterns whose practice is not matched by adequate skills and professionalism. This is certainly not in line with the modern management concept recently practiced by many pesantren.

Modern pesantren management has recently implemented a management function with the planning, organizing, actuating, and controlling (POA) stages - often referred to as POAC. Introduced by George R. Terry, ${ }^{44}$ POAC has become a principle of organizational management, including for pesantren institutions. The success of pesantren modernization

\footnotetext{
${ }^{43}$ This category refers to Kafrawi, which confirms that pesantren have experienced changes in both content and form in the history of his journey so that there are five types of pesantren adults. Two of them are the second pattern. The pesantren has a hut or dormitory provided for students who come from other regions. The teaching methods are sorogan and wetonan. The third pattern, Pesantren, has adopted a classical system, where students get an education in a madrasah and teaching in the sorogan and weton conducted by the Kiai. Kafrawi, Pembaharuan Sistem Pendidikan Pondok Pesantren (Jakarta: Cemara Indah, 1978), p. 26-28.

${ }^{44}$ George R. Terry, Principles of Management (Illinois, 1968).
} 
needs to be supported by the leadership's ability to apply these management principles, in this case, the Kiai and other pesantren managers. Starting with: 1) planning, designing long-term plans to achieve goals; 2) organizing, managing teams/divisions, work schedules, working groups, and optimizing all available resources, especially human resources, to transform plans into concrete actions; 3) implementation, actualization and implementation of plans according to the work program that has been prepared; and ends with control, to ensure business workflow goes according to plan. At all these stages, the Kiai leadership is the primary key to success. What is Kiai's role in leading the four pesantren that were the samples of this research?

\section{Modernization of Education and Teaching Systems}

When viewed in its function as an institution tafaqquh fiddin (exploring Islamic religious knowledge) and its purpose as a custodian, developer, announcer, and preserver of Islamic teachings, the four institutions have carried out these functions. ${ }^{45}$ All four are places for teaching Islamic religion, particularly those related to Arabic, such as nahwu, sharaf, bayan, badi, and ma'ani, and knowledge about shariah, such as the science of jurisprudence, both the worship and mu'amalat parts. Besides, the pesantren also teaches knowledge related to the Qur'an and its interpretations, traditions and traditions, cultures of monotheism, the science of mantiq, the science of dates, and tasawuf. ${ }^{46}$

Even general knowledge, which was not previously a compulsory subject, began to be taught in pesantren, in line with the opening of the classical education system. ${ }^{47}$ Besides, in terms of society, the four pesantren have also carried out maintenance and mental education functions. ${ }^{48}$ The material consists of how to write and read the Qur'an and other Islamic religious sciences, such as Tool Sciences which include Nahwu, Sharaf, Balaghah, Ma'ani, and Bayan, in Tafsir using the Tafsîr Jalâlain, using Fiqh in the Science of Jurisprudence the book of Fath al-Qarîb, even teaches folklore. ${ }^{49}$

The four Pesantren have so far made adaptations in the fields of education and teaching. This is done to maintain and maintain the continuity of pesantren. In the scientific area, adjustments are made by increasing the scientific quality of the caregivers. The Kiai studied

${ }^{45}$ Tatang Muttaqin, et al., "The Achievement Gap in Indonesia? Organizational and Ideological Differences between Private Islamic Schools," in School Effectiveness and School Improvement, Vol. 31, No. 2, 2020, p. 212-242.

${ }^{46}$ Martin Van Bruinessen, Kitab Kuning, Pesantren dan Tarekat, Tradisi-Tradisi Islam di Indonesia (Bandung: Mizan, 1995), p. 149-168.

${ }^{47}$ Eka Srimulyani, "Islamic Schooling in Aceh: Change, Reform, and Local Context," in Studia Islamika, Vol. 20, No. 3, 2013, p. 467-487.

${ }^{48}$ Rahardjo, Pesantren dan Pembaharuan, p. 83.

${ }^{49}$ Andik Wahyun Muqoyyidin, "Kitab Kuning dan Tradisi Riset Pesantren di Nusantara," in Jurnal Kajian Islam dan Budaya, Vol. 12, No. 2, 2014, p. 119-136. 
with his parents and studied with famous scholars, both caretakers of pesantren in cities and scholars in the Middle East. This was done, for example, by the caretakers of the alMusyarrofah pesantren. Sheikh Arifuddin studied at the Ampel Denta pesantren in Surabaya and Giri Kedaton in Gresik, while Sheikh KHR Abdul Mu'thi studied at Makkah al-Mukarramah and Madinah al-Munawwarah. As for KH Wildan Afandi studying in Sukabumi and Majalengka, KH. Acep Abdul Wahid studied in the Darurrahman pesantren led by KH. Syukran Ma' mun, until he obtained his Bachelor's Degree in Islamic Religious Education.

Similar practices were carried out by caretakers of the as-Syuja'i pesantren who besides studying at the Sumursari pesantren in Garut, also at the Gentur pesantren, Warung Kondang Cianjur, pesantren in Tangerang Banten, pesantren at Jembatan Lima West Jakarta, pesantren in Central Java, pesantren in Sukabumi and several other pesantren. Likewise, Darul Falah pesantren, KH. Fachruddin, and KH. Aang Muhyiddin studied in Makkah alMukarramah. On his return from Makkah studied in Gentur pesantren by analyzing KH. Ahmad Qurtubi and KH. Ahmad Syatibi. While the caretakers of Darussuada al-Amin Pesantren, $\mathrm{KH}$. Ahmad Musthofa Yahya studied at the pesantren Degree, then went to Cibitung Bandung and finally studied at the Gentur pesantren.

The four pesantren have done this by establishing prestigious educational institutions related to adaptation in education. Darul Falah pesantren and Darussuada al-Amin pesantren were once the targets of protests and criticism from the surrounding community because they only established madrasa-level education institutions, and early childhood education eventually made adjustments. However, in general, efforts to adapt have not gone well. Many technical matters hampered the Darul Falah pesantren and Darussuada al-Amin pesantren's adaptation process, especially in education and teaching. The main factor comes from the lack of innovation from the pesantren leaders and managers, apart from the facilities' limited support. There is no precise formulation regarding the strategic plan used in designing the education and teaching system.

In contrast to the other two pesantren, the al-Musyarrofah pesantren and the asSyuja'i pesantren have successfully adapted. In addition to implementing traditional pesantren teaching, the two pesantren have also developed modern education by introducing classical education. Al-Musyarrofah pesantren successfully established the kindergarten of al-Qur'an, Madrasah Diniyah, Madrasah Ibtidaiyah, Integrated Islamic Middle School, and Integrated Islamic Vocational School, and positioning itself as a Semi-Modern educational institution. Likewise, the as-Syuja'i pesantren had succeeded in establishing the Madrasah Tsanawiyah, and a year later, in 1982, opened a high school, where the number of students was vast. Formal schools at the Ibtidaiyah level were not held because there were already many elementary schools around the lodge. However, in high school educational institutions, it also teaches the Qur'an, Tafsir, and Arabic.

The key to success can be seen from a reasonably mature planning aspect. Both pesantren al-Musyarrofah and pesantren as-Syuja'i develop strategic plans on the aspects 
of education and teaching. They realize the importance of adaptive pesantren to change and respond to globalization challenges. This needs to be supported by an education and teaching system that can answer the challenges of the industrial revolution era 4.0, of course, without leaving all its peculiarities. The initial role of Pesantren was conventionally transferring Islamic religious knowledge and producing ulama cadres. However, over time, pesantren applies the principle of "continuity in the middle of change" (continuity and change). This can be seen from several essential aspects, namely: curriculum, quality assurance of education, the profile of graduates, profiles of educators, and education personnel.

Pesantren al-Musyarrofah, for example, in the curriculum aspect, development is carried out through a learning system that answers the times' needs, significantly strengthening Arabic and English as the official language of communication. In addition to language, students are also guided to be able to memorize the Qur'an at least five juz, memorize the hadiths of at least 200 matan, and of course, understand the basics of the yellow book. This becomes the flagship program of the pesantren, which has great benefits when the students graduate. The curriculum used is a combination of a modern and traditional cottage and the national curriculum. Santri, who graduated, will get two diplomas (SMKand Pesantren). This is undoubtedly very useful for students to continue their studies to a higher level and their capital to serve in the community.

The same thing was done by pesantren as-Syuja'i, using the pesantren curriculum, which is integrated with the government curriculum. Integrating general education and religious education into one curriculum fabric is a strategic step for pesantren, as is the case in integrated Islamic schools. With this approach, all subjects and all pesantren activities cannot be separated from the framework of Islamic teachings and values. General subjects, such as mathematics, science, social studies, language, body/health, are framed by Islamic footing, guidelines, and guidelines. While studying religion, the curriculum is enriched with contemporary context approaches and benefits and benefits.

In addition to strengthening the curriculum, the two of them also strengthen the education quality assurance system. As mandated by Law No.18 of 2019 concerning pesantren, in particular, Article 26 that pesantren are presented to ensure the quality of pesantren education. Its functions are 1) to protect the independence and uniqueness of pesantren education, 2) to realize quality education, and 3) promoting the implementation of pesantren education. Compiled by the Masyayikh Council, the quality assurance system is directed at improving the quality and competitiveness of resources, strengthening management, and increasing support for pesantren facilities and infrastructure. The Masyayikh Council, which is led by a Kiai, has the following tasks: 1) to compile a curriculum; 2) carry out learning activities; 3 ) increasing the competence and professionalism of educators and educational staff; 4) carry out exams to determine the graduation of students based on predetermined quality criteria, and 5) submitting the data of the students who passed to the Masyayikh Council which is the representative of the Masyayikh Council. 
With this structure, pesantren al-Musyarrofah and pesantren as-Syuja'i strive to strengthen the quality assurance system optimally. Both pesantren believes that the indicator of a quality Islamic education institution is if its output can impact society. The principle of balance becomes a reference, especially to unify religious education and general education proportionally. Through strengthening the education quality assurance system, it is expected that besides scholars who can accommodate all the phenomena of their life following the teachings or basis of the Qur'an and Hadith who have competitive skills in the field of science and technology according to the times.

It is essential to underline that modernizing the education and teaching system in pesantren is also influenced by facilities and infrastructure availability. ${ }^{50}$ This has been the concern of pesantren managers from the beginning. ${ }^{.1}$ The fact that pesantren students come from various regions, not only from the cottage area, encourages pesantren managers to strengthen infrastructure aspects. A large number of students in pesantren resulted in the emergence of student's bats and settlers. This has encouraged pesantren managers to be more active in building dormitories and accommodation. If boarding and boarding were initially made of simple materials, from bamboo and wood and brick, in the development, the bedroom was made in the form of a permanent and multi-story building to accommodate many students.

Regarding the condition of infrastructure, all four pesantren have permanent buildings, both terraced and non-terraced. The number of buildings varies in each pesantren, but the functions are still similar. As-Syuja's pesantren, for example, has a small amount of student dormitory buildings because there are relatively few students living there. Nevertheless, as-Syuja'i pesantren has quite many school buildings. The opening of formal educational institutions, such as the Madrasah Tsanawiyah, ${ }^{52}$ Moreover, High Schools, ${ }^{53}$ A year later, precisely in 1982. While traditional schools at the Ibtidaiyah level were not held because around the huts, there were already many standing Primary schools. However, in high

${ }^{50}$ Lukman Hakim, Mohammad Abdul Khalid, and Fahcrurriza Oktaviana Suyoto Putri, "The Role of Pesantrens in Forming Entrepreneurship Values and Religious Leadership of Santri," in Journal of Islamic Education, Vol. 3, No. 2, 2019, p. 98-110.

${ }^{51}$ Muhammed Latif, "Multicultural Education In Pesantren," in Journal of Islamic Civilization in Southeast Asia, Vol. 5, No. 2, 2016, p. 231-250.

${ }^{52}$ Mama Dayat, explained that she had not established a Madrasah Tsanawiyah because there was no consensus among them. In this case, Mama Dayat kept it a secret. Still, after Mama Syuja'i died and those who did not agree also died, by saying Bismillah, Mama Dayat in 1981 opened the junior high school level institution. Abdul Aziz Hidayatullah, Caregiver of as-Syuja'i Pesantren, interview in Cilaku, Cianjur, West Java, September 13, 2018.

${ }^{53}$ This institution was founded, among others, motivated by the limited number of formal schools at the senior high school level. In contrast, other arguments, because by chance, a sonin-law worked as a civil servant placed in the Ministry of Religion in Cianjur Regency. His son was also a public servant who was set in the Cianjur Regency Education Office. Abdul Aziz Hidayatullah, Caregiver of as-Syuja'i Pesantren, interview in Cilaku, Cianjur, West Java, September 13, 2018. 
school educational institutions, it also teaches the Qur'an, Tafsir, and Arabic. In 1991, especially during the $\mathrm{KH}$. Abdul Aziz Hidayatullah, the pesantren formed the al-Maziyyah Education Foundation. This was done in addition to responding to the times' demands and improving students' quality and quantity.

Like the as-Syuja'i pesantren, the number of buildings in the al-Musyarrofah pesantren is enormous, consisting of buildings for dormitories, buildings for formal schools, and other structures, because the al-Musyarrofah pesantren, besides organizing traditional recitation activities, also opened a new school with relatively modern management. From the first generation to the fourth generation, the building was made, renovated in the fifth generation, and significant renovations occurred in the sixth generation.

This happened along with the adaptation in the institutional aspect. To respond to the times' demands, Al-Musyarrofah pesantren changed the lodge's management by establishing the foundation. This practice began in Sheikh KH. Wildan Afandi, which was then forwarded by KH. Acep Abdul Wahid, an energetic young cleric, who presented a new pesantren. During the $\mathrm{KH}$. Acep Abdul Wahid and expanding land by buying land owned by residents, it also built many multi-story buildings as dormitories and student learning facilities. This is a form of adaptation in infrastructure. By creating student dormitories in permanent structures and expanding land, it is hoped that students' quality and quantity will also improve.

The adaptation process was successfully carried out, marked by the increasing number of pesantren students. The structuring of the development program was intensively carried out, starting from 2002, the establishment of Madrasah Diniyah, then in 2004, the AlQur'an and Ibtidaiyah Educational, and in 2008, the Modern Al-Musyarrofah pesantren accompanied by establishing al-Musyarrofah IT Middle School, and then followed by the establishment of SMK IT in 2011. Students in the first batch totaled 18 people consisting of 12 men and six women. However, now the number has increased to 650 people, consisting of 300 settler students who are junior and vocational high school students, and 350 nonsettler students who are Madrasah Diniyah, Madrasah Ibtidaiyah, and Taman Pendidikan Al Qur'an (TPA). As many as 50 people, teachers, and staff are under the pesantren leadership, including KH. Acep Abdul Wahid, Ihas Rafiqah, and Elis Riana. ${ }^{54}$

Compared to the As-Syuja'i pesantren and the al-Musyarrofah pesantren, there is not too much infrastructure in the Darul Falah pesantren. This is because the Darul Falah Pesantren only organizes pesantren activities and does not conduct classical education, except Madrasah Diniyah with 30 students. Teaching is carried out through recitation, divided into two units, a unit in the east with 70 students, during a group in the west with 15 students. Besides, the pesantren also conducts religious studies for men and women

\footnotetext{
${ }^{54}$ Elis Riana, Caregiver of al-Musyarrofah Pesantren, interview in Warung Kondang, Cianjur, West Java, September 19, 2018.
} 
from the community around the lodge. Generally, students go back and forth, but some mukim students come from a fairly remote area.

Similar conditions apply to Darussuada al-Amin pesantren. Not many dormitory buildings were built, even less than the infrastructure at Darul Falah pesantren. In the Darussuada al-Amin pesantren and early childhood education with 30 students, a pesantren education with 50 female students and 40 female students was held. They are bunk students and resident students who live in dorms. It appears that the number of dormitories available with the number of students living there is not comparable. As a result, the room became full and felt lacking when Darussuada pesantren carried out religious activities, such as the Pesantren Kilat (SANLAT). The same thing happened when Darul Falah organized SANLAT activities. Space limitations are a problem for both pesantren.

However, as part of strengthening infrastructure facilities, the Darul Falah pesantren, the Darussuada al-Amin pesantren, the al-Musyarrofah pesantren, and the as-Syujai pesantren also established foundations. With this foundation, the pesantren is expected to become more productive. However, of course, foundations do not guarantee pesantren success in developing institutions in general. This can be seen from Darul Falah's condition and the Darussuada al-Amin pesantren, which is different from the al-Musyarrofah the as-Syuja'i pesantren.

\section{The Role of Kiai Leadership in Pesantren Modernization}

The success of pesantren in adapting to the times' demands is closely related to the Kiai's leadership. ${ }^{55}$ Adaptation of education and teaching and adjustment of facilities and infrastructure is highly dependent on the commitment of the Kiai in managing the pesantren and seeing the case of the Darul Falah the Darussuada al-Amin pesantren. The al-Musyarrofah pesantren and the As-Syuja'i pesantren, the kiai's leadership factor, are very decisive. In maintaining the enthusiasm of institutions that prioritize leadership regeneration in family members' hands, the four pesantren were quite successful.

Pesantren caregivers come from the family environment. ${ }^{56}$ The four pesantren still use the old pattern, where when there is a boy who is qualified in science, he is immediately prepared to continue. If there is no son, the daughter is married to a student who is smart and reliable. For example, the al-Musyarrofah pesantren married his daughter $\mathrm{Hj}$ Khadijah with Sheikh KH. Afandi Zuhdi, the son of a wealthy landowner. After Shaykh KHR. Abdul

${ }^{55}$ Ahmad Iwan Zunaih, Sebastian Koto, and Praptining Sukowati, "Kiai Leadership Model In Development Strategy Pesantren," in Journal of Humanities And Social Science, Vol. 24, No. 1, 2019, p. 41-46.

${ }^{56}$ Sudak, Udji Asiyah, and Ratna Azis Prasetyo, "The Role of Pesantren as Socialization Agent of Ecological Values (A Case Study in Salaf-Modern Pesantren)," in Wacana, Vol. 20, No. 4, 2017, p. 9-18. 
Mu'thi died, he got the mandate to replace him as a pesantren caretaker. H. Husen pioneered the establishment of the as-Syuja'i pesantren, married his daughter $\mathrm{Hj}$. Siti Khadijah with H. Muhammad Syujai, and then gave all assets in the form of land, cottage buildings, and rice fields to him. After KH. Muhammad Syuja'i died, the hut's mandate was handed over to his son-in-law KH. Abdul Aziz Hidayatullah. Likewise, after he died, KH. Muhammad Chalil, founder of the Darul Falah pesantren, handed over pesantren care to his son-inlaw. After KH. Fachruddin died, the pesantren responsibility was handed over to his son KH. Aang Muhyiddin. While the founder of Darussuada al-Amin pesantren, KH. Musthafa Yahya, after his death handed over the hut's care to his son and after KH. Ahmad Shafiyullah died, the responsibility of the shelter was handed over to his son H. Aang Fauzi until now.

However, in the current condition, Pesantren's management can no longer be built only by the pattern of family relations but demands more professionalism and quality human resources. The cases of the Darul Falah pesantren and the Darussuada pesantren are interesting to note. Both of them are seen as 'living reluctantly to death,' a condition which is quite alarming. In infrastructure, Darussuada pesantren has a vast land but only has fewer than 100 students. This causes pesantren caregivers to create their activities. Some open early childhood educational institutions focus on implementing pesantren activities and several other religious education activities. Something similar happened at the Darul Falah pesantren. Among the caregivers, there was a 'conflict' that caused the learning process to be disrupted. A caregiver conducts recitation with less than 20 people, while another caregiver can lead the narration with several students of more than 75 people.

Both of the above cases imply a problem surrounding the leadership of the Kiai. The absence of charismatic Kiai figures is the main problem faced by the two pesantren. While in modern management, leadership becomes an essential aspect of institutional development, especially in generating innovative, creative ideas that can bring pesantren to develop along with the dynamics and changes in social institutions. ${ }^{57}$ The Kiai will also determine the pesantren vision and mission. ${ }^{58}$

Meanwhile, if look at pesantren al-Musyarrofah and pesantren as-Syuja'i, both succeeded in launching the modernization of education because their leaders had innovative ideas accompanied by strategic actions. The leadership of the Kiai in pesantren al-Musyarrofah and pesantren as-Syuja'i, which is innovative and communicative, is a factor in the readiness of the pesantren to modernize education. In the case of the Al-Musyarrofah pesantren, $\mathrm{KH}$. Wildan Afandi is interesting. Apart from being a Kiai, the leader of the pesantren, he is also

${ }^{57}$ Biyati Ahwarumi and Tjiptohadi Sawarjuwono, "Enhancing Innovation Roles of Pesantren Business Incubator in Pondok Pesantren Sunan Drajat," in Journal of Innovation in Business and Economics, Vol. 1, No. 2, 2017, p. 71.

${ }^{58}$ Noor Hamid and Muhammad Iqbal Juliansyahzen, "Prophetic Leadership in Pesantren Education: Study at Pondok Pesantren Universitas Islam Indonesia," in Jurnal Pendidikan Islam, Vol. 6, No. 2, 2017, p. 349. 
an activist of the Islamic movement who was once the Chairman of the Anshar Youth Movement in Cianjur (1952), founded the Majalengka Branch of NU (1954), co-founded the NU Party chaired by Dr. KH. Idham Khalid and became a national campaign team with $\mathrm{KH}$. Syukran Ma'mun and being a member of the DPRD Majalengka Regency, a delegation from NU. His experience and extensive network are essential assets in the modernization process of pesantren. He was starting with a change in management, marked by establishing a foundation and a change in the name of the pesantren, from Ciwalen to Pondok Pesantren al-Musyarrofah.

The success of modernizing education was increasingly seen when in 2002, the leadership of the al-Musyarrofah pesantren deed a new foundation by placing several human resources with the best capabilities and competencies to sit as unit leaders, both Head of Madrasah Diniyah and other educational units, including for the position of Head of the Taman Pendidikan School al-Qur'an and the Head of Madrasah Ibtidaiyah (in effect since 2004). Since then, the development program has been structured, until 2008 the AlMusyarrofah Modern Pesantren was established by establishing the Al-Musyarrofah Islamic Junior High School (SMP IT), followed in 2011 by establishing an Integrated Islamic Vocational High School (SMK IT). As the pesantren's institutional management is strong, the number of students has also increased significantly, from 18 people at the start of its establishment to 650 in $2018 .^{59}$

Likewise, the pesantren as-Syuja'i. KH's experience and network. Muhammad Syuja'i, as the leader of the pesantren, greatly determines the success of the education modernization agenda. Like KH. Wildan Afandi, KH. Muhammad Syuja'i also became an activist for Nahdlatul Ulama, most recently as Deputy Rais Syuriah PW NU West Java until 1983, with an unquestionable commitment. This made it easier for him to move to develop pesantren with the support of critical Islamic figures, such as al-Habib Muhammad alHaddad (Tegal), al-Habib Syekh bin Salim al-Attas (Sukabumi), al-Habib Utsman alIdrus (Bandung). ${ }^{60}$ The modernization of education was increasingly visible with the establishment of the al-Maziyyah Education Foundation and the presence of Junior and Senior High Schools during the leadership of Ajengan Dayat. Both educational institutions are proliferating, with the number of students reaching 1000 people. Ajengan Dayat has increasingly presented innovative ideas for pesantren as he is increasingly active in district government agencies. When he was a member of the DPRD for three periods, he found modern ideas in the realm of education and was integrated into the pesantren's management. ${ }^{61}$

Learning from the Al-Musyarrofah pesantren and as-Syuja'i pesantren case, aspects of professionalism and quality human resources are the key for pesantren to adapt. This

\footnotetext{
${ }^{59}$ Elis Riana, Caregiver of Pondok Pesantren Modern al-Musyarrofah, interview in Warung Kondang, September 19, 2018.

${ }^{60}$ Halim, Asyarie and Bahrudin, Kyai dari Tatar Murid, h. 89-90.

${ }^{61}$ Ibid., h .91.
} 
confirms that pesantren management practices that still rely on paternalistic or feudalistic management models need to be renewed. Pesantren managers often use family relations without prioritizing professionalism. Besides, many pesantren leaders are involved in practical politics by ignoring the management of pesantren. This pattern indeed becomes an obstacle to the development and improvement of the quality of education in pesantren.

However, on the other hand, appreciation should be given to pesantren, who tries to adjust to modern management. ${ }^{62}$ They believe that globalization brings challenges but also promising opportunities for pesantren to progress and develop. ${ }^{63}$ Many pesantren, which initially only prioritized religious studies and aimed at producing cadres of ulama's development, have now changed by offering a more modern curriculum.

Many pesantren have changed their orientation. These changes are mainly influenced by new developments outside the pesantren, such as Pesantren figures' intersection with globalization. ${ }^{64}$ Besides, various Ministry of Religion policies also contributed to reform carried out by pesantren managers. Thus, the management of the pesantren, community demands, global developments, and the Ministry of Religion's policies are factors that play a role in the ongoing process of reform and modernization of the pesantren. Many of the pesantren leaders have practiced it and succeeded in bringing the pesantren to become better institutionally. In the end, the pesantren readiness factor in responding to modernity becomes a fundamental principle in positioning the pesantren with all its peculiarities.

\section{Conclusion}

The readiness factor in responding to globalization has become a fundamental principle in positioning pesantren with all their uniqueness as traditional Islamic educational institutions. For pesantren, globalization's impact affects pesantren in several aspects, namely institutional systems, organizational patterns, study orientation, and curriculum, to teaching and learning methods. The initial role of pesantren was conventionally transferring Islamic religious knowledge and producing ulama cadres. In modern developments, pesantren are facing new challenges, particularly in response to the latest developments, while on the other hand, they are still trying to meet the educational needs of modern society. The challenges are quite fundamental, mainly related to the institutional and managerial patterns

${ }^{62}$ Nurul Azizah, "From Mullah to Regent: The Study of Leadership Alteration from Pesantren to the Secular Leadership Lecturer of Sociology," in International Journal of Humanities and Social Science, Vol. 3, No. 10, 2013, p. 228-238.

${ }^{63}$ A Suradi, "Transformation of Pesantren Traditions in Face the Globalization Era Introduction In General: Pesantren Can Be Distinguished to the Pesantren of Khalafiyah and Salafi. The Teaching System Used Classical Methods. This Method Is Known as the Sorogan," in Nadwa: Jurnal Pendidikan Islam, Vol. 12, No. 51, 2018, p. 27-38.

${ }^{64}$ Ronald Lukens-Bull, "Pesantren, Madrasa and the Future of Islamic Education in Indonesia," in Kawalu: Journal of Local Culture, Vol, 6, No. 1, 2019, p. 29. 
of pesantren, which are still ongoing and must be addressed to an improved strategy within the "education industry," which demands competitive and comparative advantages as high competitiveness.

However, it must be admitted that even though it has entered the era of globalization, pesantren are still facing various managerial problems. Many management practices in pesantren still rely on paternalistic or feudalistic management models. Pesantren managers often use kinship relations without prioritizing professionalism. This pattern is undoubtedly an obstacle to developing and improving the quality of education in the pesantren.

Pesantren al-Musyarrofah and pesantren as-syuja'i provide lessons related to the importance of the leadership's ability to seek government support, religious, social institutions, and community organizations developing pesantren. The struggle for innovative ideas obtained from pesantren leaders' friendship networks in state institutions, religious, social institutions, and community organizations is an essential provision for accelerating pesantren's modernization. The three institutions also provide insight and a way for the modernization of pesantren, including input regarding strategic steps to deal with the problems. This explains why pesantren al-Musyarrofah and pesantren as-syuja'i were able to survive as traditional Islamic educational institutions. With his charisma, pesantren Kiai has a greater chance of successfully leading the modernization agenda, especially if he can build networks and communication with the government, religious, social institutions, and community organizations.

The four pesantren still maintain several things that are characteristic of the pesantren. They, for example, continue to make aspects of traditional Islamic education at the heart of pesantren. The yellow book of salaf ulama works is still used in each pesantren. These books are learning resources that have been used by the four pesantren since they were first established. Even traditional learning methods, such as sorogan and bandongan, which incidentally are also still maintained as the fourth learning system of pesantren. Kiai, students, mosques, huts or dormitories, and teaching classical Islamic books are always maintained.

However, changes in institutions and leadership in the four pesantren are a must. Responding to the development of the times and society's demands, the four did not hesitate to tidy up and change, including the modernization of pesantren teaching and institutional change. In addition to the mission of preaching, the four also faithfully present superior quality human resources, competitive and religious. However, some pesantren has successfully adapted; some have been less successful. This finally helped determine the ups and downs of the pesantren.

In this context, creativity and innovation are the determinants of whether the pesantren will adapt to changes that occur or vice versa, stay put. The four pesantren educational institutions are very likely to experience stagnation when pesantren leaders cannot maintain commitment and are less responsive to developments. This is especially so if the pesantren leadership is less communicative and lacks networking. Because the modernization of 
pesantren is not enough to only rely on the Kiai charisma, it also needs to be supported by the Kiai's ability to integrate the latest developments in the management structure of the pesantren. Modern management combined with the Kiai charisma is the success factor for the pesantren to survive globalization's onslaught.

\section{References}

Aang Fauzi, Caregiver of Darussuada al-Amin Pesantren, interview in Cilaku, Cianjur, West Java, September 42018.

Abdul Aziz Hidayatullah, Caregiver of as-Syuja'i Pesantren, interview in Cilaku, Cianjur, West Java, September 132018.

Aboebakar. Sejarah Hidup KH. A. Wahid Hasyim. Bandung: Mizan, 2011.

Acep Abdul Wahid, Caregiver of al-Musyarrofah Pesantren, interview in Warung Kondang, Cianjur, West Java, September 182018.

Ade Ismail, Caregiver of Darul Falah Pesantren, interview in Jambudipa, Cianjur, West Java, August 132018.

Ahdar, Abdul Halik, and Musyarif. "Moderation and Mainstream of Pesantren/Madrasah Education," in Media Komunikasi Sosial dan Keagamaan, Vol. 13, No. 1, 2020.

Ahwarumi, Biyati and Tjiptohadi Sawarjuwono. "Enhancing Innovation Roles of Pesantren Business Incubator in Pondok Pesantren Sunan Drajat," in Journal of Innovation in Business and Economics, Vol. 1, No. 2, 2017.

Ajeng Masykur, Caregiver of Darussuada al-Amin Pesantren, interview in Cilaku, Cianjur, West Java, September 52018.

Ali, Abdul Mukti. Alam Pikiran Islam Modern Di Indonesia. Yogyakarta: Yayasan Nida, 1971.

Arifin, Imron. Kepemimpinan Kiyai: Kasus Pondok Pesantren Tebu Ireng (Malang: Kalimashada Press, 1993)

Arifin, Imron \& Muhammad Slamet. Kepemimpinan Kyai dalam Perubahan Manajemen Pondok Pesantren: Kasus Ponpes Tebuireng Jombang. Yogyakarta: CV Aditya Media, 2010.

Azizah, Nurul. "From Mullah to Regent: The Study of Leadership Alteration from Islamic Boarding School to the Secular Leadership Lecturer of Sociology," in International Journal of Humanities and Social Science, Vol. 3, No. 10, 2013.

Bruinessen, Martin Van. Kitab Kuning, Pesantren Dan Tarekat, Tradisi-Tradisi Islam Di Indonesia. Bandung: Mizan, 1995.

Burhanudin, Jajat and Dina Afrianty. Mencetak Muslim Modern: Peta Pendidikan Islam Indonesia. Jakarta: RajaGrafindo Persada, 2006.

Chairul Anam, Caregiver of Darul Falah Pesantren, interview in Jambudipa, Cianjur, West Java, August 142018. 
Dhofier, Zamakhsyari. Tradisi Pesantren Studi Tentang Pandangan Hidup Kyai. Jakarta: LP3ES, 1982.

Djunaedi, M. "Revitalization Of Islamic Education," in Journal of Islamic Education, Vol. 7, No. 1, 2019.

Elis Riana. Caregiver of al-Musyarrofah Pesantren, interview in Warung Kondang, Cianjur, West Java, September 192018.

Gaus, Djulaiha. "Pendidikan Islam Indonesia Dan Tantangan Globalisasi: Perspektif SosioHistoris," in Ibriez: Jurnal Kependidikan Dasar Islam Berbasis Sainsurnal Kependidikan Dasar Islam Berbasis Sains, Vol. 2, No. 1, 2017.

Hakim, Lukman, Mohammad Abdul Khalid, and Fahcrurriza Oktaviana Suyoto Putri. "The Role of Islamic Boarding Schools in Forming Entrepreneurship Values and Religious Leadership of Santri," in Journal of Islamic Education, Vol. 3, No. 2, 2019.

Halim, KHR Abdul, Rudi Asyarie and Ending Bahrudin. Kyai Dari Tatar Murid. Cianjur: Yaspumah, 2014.

Halim, KHR Abdul, Rudi Asyarie and Ending Bahrudin. Ulama Jumhur Dari Cianjur. Cianjur: Yaspumah, 2016.

Hamid, Noor and Muhammad Iqbal Juliansyahzen. "Prophetic Leadership in Pesantren Education: Study at Pondok Pesantren Universitas Islam Indonesia," in Jurnal Pendidikan Islam, Vol 6, No. 2, 2017.

Hasyim, Abdul Wahid. Pesantren Langitan Pusat Pencerahan Intelektual Ummat. Bekasi: Pascasarjana Unisma, 2008.

Hefner, Robert W. Making Modern Muslims, The Politics of Islamic Education in Southeast Asia. Honolulu: Univerity of Hawaii Press, 2009.

Hefner, Robert W. \& Zaman, Muhammad Qasim (ed.). Schooling Islam, The Culture and Politics of Modern Muslim Education. New Jersey: Princeton University Press, 2006.

Idris, Fazilah, Zaharah Hassan, Azizah Ya'acob, Saran Kaur Gill, and Noor Aziah Mohd Awal. "The Role of Education in Shaping Youth's National Identity," in ProcediaSocial and Behavioral Sciences, Vol. 59, 2012.

Kafrawi. Pembaharuan Sistem Pendidikan Pondok Pesantren. Jakarta: Cemara Indah, 1978.

Kasful. "The Leadership of Kyai in Islamic Boarding School (A Study of Islamic Boarding School in Jambi)," in Al-Ta'lim, Vol. 22, No. 1, 2015.

Kusnadi, Edi, Kadir Sobur, and Arfan Aziz. "An Islamic Boarding School: A Study of AlMubarok Al-Islam Within the Social Changes of Seberang Kota Jambi," in Addin, Vol. 11, No. 1, 2017.

Latif, Muhaemin. "Multicultural Education In Islamic Boarding School," in Journal of Islamic Civilization in Southeast Asia, Vol. 5, No. 2, 2016.

Lukens-Bull, Ronald. "Pesantren, Madrasa, and the Future of Islamic Education in Indonesia," in Kawai: Journal of Local Culture, Vol. 6, No. 1, 2019. 
Maksudin. "Integration of School and Pesantren Educational System as a Model of Character Education: Perspective of Educational Transformation," International Journal on Islamic Educational, Vol. 2, No. 1, 2018.

Muazzomi, Nyimaz, and Muhammad Software. "A Qualitative Analysis of Pesantren Educational Management: School Culture and Leadership of a Professional Learning Community," in Ta'dib, Vol. 22, No. 2, 2017.

Muqoyyidin, Andik Wahyun. "Kitab Kuning Dan Tradisi Riset Pesantren Di Nusantara," in Jurnal Kajian Islam dan Budaya, Vol. 12, No. 2, 2014.

Muttaqin, Tatang, Rafael Wittek, Liesbet Heyse, and Marijtje van Duijn. "The Achievement Gap in Indonesia? Organizational and Ideological Differences between Private Islamic Schools," in School Effectiveness and School Improvement, Vol. 31, No. 2, 2020.

Nugraha, Ilham. Sejarah Berdirinya Pondok Pesantren Al-Musyarrofah. Cianjur: Pondok Pesantren Modern al-Musyarrofah, 2016.

Poerwadarminta, Wilfridus Josephus Sabarija. Kamus Bahasa Indonesia. Jakarta: Balai Pustaka, 1976.

Rafiei, Nafiseh, and Fereshte Davari. "The Role of Human Resources Management on Enhancing the Teaching Skills of Faculty Members," in Material Socio Medica, Vol. 27, No. 1, 2015.

Rahardjo, Muhammad Dawam. Pesantren Dan Pembaharuan. Jakarta: LP3ES, 1974.

Ruhyanani, Hungama. "Training Management In Islamic Boarding School (Case Study on Sidogiri's Islamic Boarding School Pasuruan)," in Journal of Social Community, Vol. 1, No. 2, 2016.

Srimulyani, Eka. "Islamic Schooling in Aceh: Change, Reform, and Local Context," in Studia Islamika, Vol. 20, No. 3, 2013.

Sudak, Udji Asiyah, and Ratna Azis Prasetyo. "The Role of Islamic Boarding School as Socialization Agent of Ecological Values (A Case Study in Salaf -Modern Islamic Boarding School)," in Wacana, Vol. 20, No. 4, 2017.

Sukamto. Kepemimpinan Kiai Dalam Pesantren. Jakarta: LP3ES, 1999.

Sunyoto, Agus. Rekonstruksi Sejarah Yang Dipinggirkan. Jakarta: Transpustaka, 2011.

Sura, A. "Transformation Of Pesantren Traditions In Face The Globalization Era Introduction In General: Pesantren Can Be Distinguished to the Pesantren of Khalafiyah and Salafi. The Teaching System Used Classical Methods. This Method Is Known as the Sorogan," in Nadwa: Jurnal Pendidikan Islam, Vol. 12, No. 51, 2018.

Suryadi and M. Mansur. "The Role of Traditional Islamic Boarding School-Based Islamic Studies as Radicalism and Intolerance Flow's Blocking Agent," in Jurnal Ilmu-Ilmu Ushuluddin, Vol. 18, No. 2, 2018.

Wajdi, Firdaus, and Rihlah Nur Aulia. "Ma'had 'Aly and the Challenge of Modernizing Islamic Education in Indonesia," in Hauula: Indonesian Journal of Multidisciplinary Islamic Studies, Vol. 3, No. 2, 2019. 
MIQOT Vol. 44 No. 2 July-December 2020

Zuhri. "Globalization and Pesantren's Response," in Trib, Vol. 2, No. 2, 2016.

Zunaih, Ahmad Iwan, Sebastian Koto, and Praptining Sukowati. "Kiai Leadership Model In Development Strategy Islamic Boarding School," in Journal Of Humanities And Social Science, Vol. 24, No. 1, 2019. 